\title{
National Alert Campaign about Increased Cholesterol. Determination of Cholesterol Levels in 81,262 Brazilians
}

\author{
Tania L. Rocha Martinez, Raul D. Santos, Dikran Armaganijan, Kerginaldo P Torres, Andréia Loures-Vale, \\ Maria Eliane Magalhães, José Carlos Lima, Emilio Moriguchi, Celso Amodeo, Juarez Ortiz \\ São Paulo, SP - Brazil
}

\begin{abstract}
Objective - To determine the levels of total cholesterol in a significant sample of the Brazilian population.

Methods - Blood cholesterol was determined in 81.262 individuals $>18$ years old $(51 \%$ male, $44.7 \pm 15.7$ years), using Accutrend equipment, in the cities São Paulo, Campinas, Campos do Jordão, São José dos Campos, Santos, Santo André, Ribeirão Preto, Porto Alegre, Rio de Janeiro, Belo Horizonte, Curitiba, Brasília, Salvador and documented in the presence of other risk factors $(R F)$ for coronary artery disease (CAD) (systemic hypertension, $C A D$ in the family, smoking, and diabetes). Participants were classified according to sex, age, and the presence or absence of $R F$, respectively, as $0 R F, 1 R F$ and $\geq 2 R F$. The percentage of individuals with cholesterol $>200 \mathrm{mg} / \mathrm{dL}$ and $>240 \mathrm{mg} / \mathrm{dL}$ was evaluated.
\end{abstract}

Results - The prevalence of individuals with 0,1 , and $\geq 2$ risk factors was $30 \%(n=24,589), 36 \%(n=29,324)$, and $34 \%(n=27,349)$ respectively, $(P=0.657)$, and the mean total cholesterol of the population was $199.0 \pm 35.0$ $\mathrm{mg} / \mathrm{dL}$. Cholesterol levels above 200 and $240 \mathrm{mg} / \mathrm{dL}$ were found, respectively, in $40 \%(n=32,515)$ and $13 \%(10.942)$ of individuals. The greater the number of risk factors the higher the levels of cholesterol $(P<0.0001)$ and the greater the proportion of individuals with cholesterol $>200 \mathrm{mg} / \mathrm{dL}$ $(P=0.032)$. No difference existed in the proportion of individuals with cholesterol $>240 \mathrm{mg} / \mathrm{dL}(P=0.11)$.

Conclusion - A great percentage of individuals with cholesterol levels above those recommended to prevent coronary artery disease was found.

Keywords: cholesterol, atherosclerosis, risk factors

Departamento de Aterosclerose e FUNCOR da Sociedade Brasileira de Cardiologia Mailing address: Raul D. Santos $\mathrm{F}^{\circ}$ - InCor/Unidade Clínica de Lípides - Av. Dr. Enéas C. Aguiar, 44 - $2^{\circ}$ andar - 05403-000 - São Paulo, SP - Brazil - E-mail: rdsf@uol.com.br
The prevalence of coronary artery disease in industrialized countries has epidemic features, and its incidence is progressively increasing in developing countries ${ }^{1,2}$.

Sedentary lifestyle and metabolic overload with diets rich in fat and calories has contributed to the increase in obesity and in adverse lipid profiles. Due to the high prevalence of coronary artery disease, preventive measures, whose benefits have been demonstrated in clinical studies, are required ${ }^{3,6}$.

The efficiency of preventive measures comes from the previous identification of the population risks and from the introduction of educational programs. Since 1990, several studies have measured the serum levels of cholesterol in isolated Brazilian populations ${ }^{7,8}$.

The present study aimed at measuring serum levels of cholesterol and identifying other risk factors in a significant population sample, including individuals from several Brazilian cities.

\section{Methods}

Between June and August 2002, the Campanha Nacional de Alerta sobre o Colesterol Elevado (National Alert Campaign about Increased Cholesterol), sponsored by the Atherosclerosis Department of FUNCOR and the Brazilian Cardiology Society assessed serum cholesterol levels and other risk factors in volunteers living in the cities of: Porto Alegre(RS), Curitiba(PR), São Paulo(SP), Rio de Janeiro(RJ), Belo Horizonte(MG), Salvador(BA), Brasília(DF), Campinas (SP), Campos do Jordão (SP), São José dos Campos (SP), Santos (SP), Santo André (SP) and Ribeirão Preto (SP).

The participants, before blood sample collection, completed a questionnaire with the purpose of identifying risk factors, including familial history of coronary artery disease, diabetes, systemic hypertension, and smoking. Capillary blood sample collection did not require fasting, and cholesterol levels were assessed using the Accutrend device (Laboratórios Roche do Brasil).

The population sample included 41.494 men and 39.769 
women, a total of 81.262 participants with ages greater than 18 years $(44.7 \pm 15.7$ years $)$.

The total number and percentage of participants in the several Brazilian cities and respective total number and percentage of individuals with serum levels of cholesterol $>200$ $\mathrm{mg} / \mathrm{dL}$ and $240 \mathrm{mg} / \mathrm{dL}$ were assessed. Mean age, number of risk factors, mean serum cholesterol levels, and the percentage of individuals from both sexes with cholesterol levels $>$ $200 \mathrm{mg} / \mathrm{dL}$ and $240 \mathrm{mg} / \mathrm{dL}$ were compared. The prevalence of risk factors was compared according to the total number of participants, mean age, and standard deviation, sex, mean serum cholesterol levels, and percentage of individuals with cholesterol levels $>200$ and $240 \mathrm{mg} / \mathrm{dL}$, respectively.

Data are expressed as mean \pm standard deviation. To compare qualitative and quantitative variables between men and women, we used the chi-square test, the Student $t$ test, and variance analysis (ANOVA). The Student-Neuman-Keuls procedure was used for posttest evaluation, and $\mathrm{P}$ values $<0.05$ were accepted as significant.

\section{Results}

The prevalence of risk factors in the population was the following: familial history of coronary artery disease in $40 \%$, systemic hypertension in $19 \%$, smoking in $16 \%$, and diabetes mellitus in $5 \%$ of the population.

The mean cholesterol level in the population studied was $199.0 \pm 35.0 \mathrm{mg} / \mathrm{dL}$. The total number and percentage of participants and the percentage of individuals with cholesterol $>200 \mathrm{mg} / \mathrm{dL}$ in the several Brazilian cities are found in table I, where it is demonstrated that 32,203 participants, that is, $40 \%$ of the population studied, has serum cholesterol levels $>200 \mathrm{mg} / \mathrm{dL}$. This percentage was also observed in the city of São Paulo, which represented $41 \%$ of the total population sample. A variation was present in the percentage levels. In Santos (SP) 57\% of participants and in Brasília (DF) $30 \%$ of the participants had serum cholesterol levels above $200 \mathrm{mg} / \mathrm{dL}$. From the population assessed, 13\% $(10,942)$ of the individuals had cholesterol $>240 \mathrm{mg} / \mathrm{dL}$.

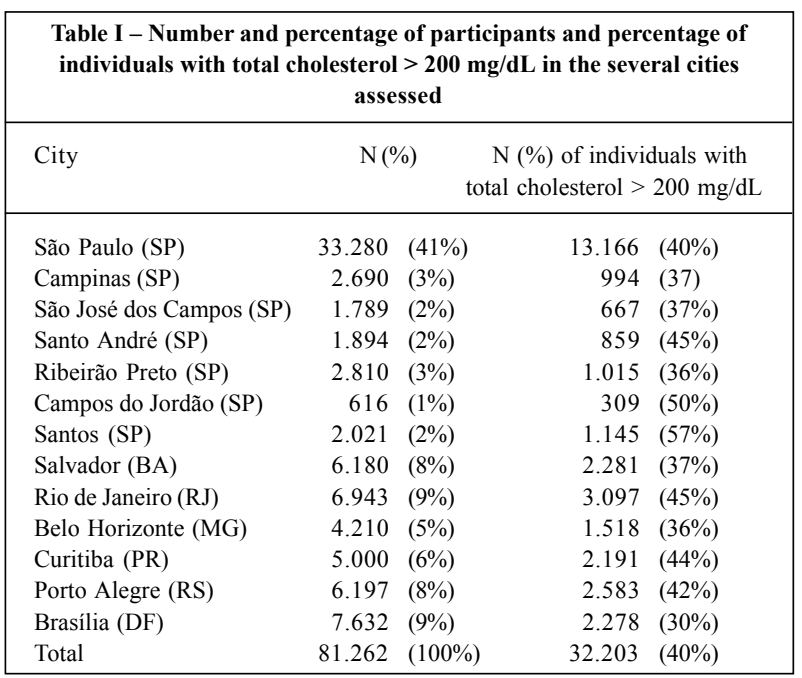

Mean ages, number of risk factors, mean serum cholesterol levels, and the percentage of individuals with cholesterol levels $>200 \mathrm{mg} / \mathrm{dL}$ and $>240 \mathrm{mg} / \mathrm{dL}$, in both sexes, are found in table II and figure 1 . Women were older than men $(\mathrm{P}<0.0001)$; however, the proportion of individuals without risk factors and with 1 or 2 or more risk factors was similar between the groups $(\mathrm{P}=\mathrm{n}$.s. $)$. Mean cholesterol values for women were greater than those for men in the whole population $(\mathrm{P}=0.0001)$ and within the subgroups without risk factors and with 1 and 2 or more risk factors $(\mathrm{P}<0.0001$, figure 1$)$. However, the proportion of men and women with total cholesterol $>200$ and $240 \mathrm{mg} / \mathrm{dL}$ was similar.

The prevalence of risk factors, when compared according to the total number of participants, mean age, sex, mean serum cholesterol levels, and percentage of individuals with cholesterol levels $>200$ and $240 \mathrm{mg} / \mathrm{dL}$ are expressed in table III. In our sample, the number of participants without risk factors and, with 1 and 2 or more risk factors was similar: 24,859 patients (30\%) did not have risk factors, 29.324 patients (34\%) had only 1 risk factor, and 27.340 (36\%) of the participants had 2 or more risk factors $(\mathrm{P}=\mathrm{n} . \mathrm{s}$. $)$. However, the greater the age of the participants, the greater the number of risk factors. The number of men and women are similar in the 3 groups. Mean cholesterol values and the percentage of participants with cholesterol $>200 \mathrm{mg} / \mathrm{dL}(\mathrm{P}<0.0001)$ increased with the number of risk factors $(\mathrm{P}=0.032)$. Howe-

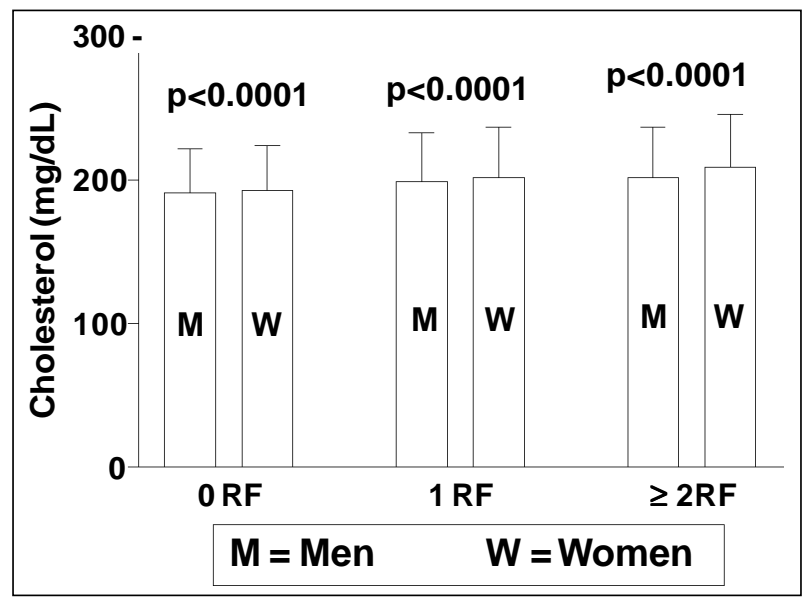

Fig. 1 - Comparison of total blood cholesterol levels between men and women without, with 1 and 2 or more risk factors for atherosclerosis

\begin{tabular}{|c|c|c|c|}
\hline & Men & Women & $\mathrm{p}$ \\
\hline $\mathrm{N}$ & 41.494 & 39.768 & - \\
\hline Age & $43.5 \pm 15.0$ & $45.9 \pm 16.4$ & $<0.0001$ \\
\hline$\%$ with risk factors: & & & 0.657 \\
\hline None & 31.7 & 29.5 & \\
\hline One & 35.0 & 36.5 & \\
\hline Two or more & 33.3 & 34.0 & \\
\hline Total cholesterol (mg/dL) & $199.0 \pm 35.0$ & $201.0 \pm 35.0$ & $<0.0001$ \\
\hline$\%>200(\mathrm{mg} / \mathrm{dL})$ & 38 & 42 & 0.66 \\
\hline$\%>240(\mathrm{mg} / \mathrm{dL})$ & 12 & 15 & 0.68 \\
\hline
\end{tabular}




\begin{tabular}{|c|c|c|c|c|}
\hline \multicolumn{5}{|c|}{$\begin{array}{l}\text { Table III - Comparison of clinical data and cholesterol values } \\
\text { between individuals without, with one or } 2 \text { or more risk factors for } \\
\text { atherosclerosis in the assessed population }\end{array}$} \\
\hline Risk factors & None & One & Two or more & $\mathrm{P}$ \\
\hline $\mathrm{N}$ & 24.859 & 29.324 & 27.349 & - \\
\hline $\begin{array}{l}\text { Age } \\
\text { Gender \% }\end{array}$ & $34.9 \pm 10.4$ & $44.4 \pm 15.4$ & $53.9 \pm 14.4$ & $<0.0001$ \\
\hline Male & 52.4 & 50.4 & 50.5 & 1.0 \\
\hline Female & 47.6 & 49.6 & 49.5 & \\
\hline $\begin{array}{l}\text { Total cholesterol } \\
(\mathrm{mg} / \mathrm{dL})\end{array}$ & $192.0 \pm 31.0$ & $200.0 \pm 35.0$ & $205.0 \pm 36.0$ & $<0.0001$ \\
\hline$\%>200(\mathrm{mg} / \mathrm{dL})$ & 30 & 41 & 48 & 0.032 \\
\hline$\%>240(\mathrm{mg} / \mathrm{dL})$ & 8 & 14 & 18 & 0.11 \\
\hline
\end{tabular}

ver, the percentage of individuals with cholesterol greater than $240 \mathrm{mg} / \mathrm{dL}$ was similar between the groups.

\section{Discussion}

In Brazil, the latest DATASUS data demonstrate that stroke and coronary disease are the main causes of cardiovascular mortality 9 . The increasing trends of these clinical complications of atherosclerosis indicates the need for campaigns to identify the risk factors in the population and the introduction of educational programs.

Clinical studies of intervention with lipid-lowering medications demonstrate that controlling cholesterol reduces the incidence of both coronary disease and stroke $\mathrm{e}^{2-6,10}$. The benefit of intervention is particularly noticeable when risk of clinical events ${ }^{11}$ is increased.

The national campaign to warn about high cholesterol is aimed at measuring serum levels of cholesterol, identifying risk factors, and warning the population about the need to prevent cardiovascular disease.

Determination of cholesterol levels was performed in a large population sample. Mean cholesterol values of the population were within the limits recommended by the III Diretrizes Brasileiras de Dislipidemias e Prevenção de Aterosclerose da Sociedade Brasileira de Cardiologia ${ }^{12}$ (Brazilian Recommendation for Dyslipidemia and Atherosclerosis Prevention from the Brazilian Cardiology Society), although a great part of the population had values above the goals proposed and about $15 \%$ of the sample had hypercholesterolemia.

Relative risk of cardiovascular events increases in the population whose cholesterol levels are $>200 \mathrm{mg} / \mathrm{dL}^{13}$. In the Framingham study, the mean cholesterol level was 225 $\mathrm{mg} / \mathrm{dL}$ in the population with myocardial infarction 14 . Because of this elevated cholesterol level, people with myocardial infarction, a minority of the study population, were at greater risk. In our sample, $40 \%$ of the participants had serum cholesterol levels $>200 \mathrm{mg} / \mathrm{dL}$, suggesting that a great number of individuals have a potential risk of cardiovascular events.
Hypercholesteremia is an independent risk factor for atherosclerosis, and its association with other risk factors increases the potential role of cholesterol ${ }^{13}$. In the Framingham study, $1 / 3$ of the population had only 1 risk factor and $2 / 3$ had 2 or more risk factors ${ }^{14,15}$.

In our study, the prevalence of none, 1 , and 2 or more risk factors was similar, in both sexes. These findings, different from those of Framingham, are due to the voluntary participation and to the exclusion of individuals who were being treated at different medical services to control risk factors. Regardless of this methodological limitation, those individuals with several risk factors are, without a doubt, at greater risk for cardiovascular events. In this sample, serum levels of cholesterol and other associated risk factors increased with age, and no significant difference existed between the sexes.

In this study and in 2 previous studies in the Brazilian population $^{7,8}$, cholesterol values were higher in women than in men in all age groups. Although the proportion of participants with cholesterol greater than $200 \mathrm{mg} / \mathrm{dL}$ and $240 \mathrm{mg} / \mathrm{dL}$ was not different between the sexes, the potential risk is greater in women because of higher cholesterol values.

Coronary disease is usually present in women after 65 years of age ${ }^{12}$. The frustrating results of estrogen replacement therapy ${ }^{16,17}$ and the satisfactory results of statins in cholesterol control, and the prevention of coronary disease in women ${ }^{3,5,6}$ enabled new guidelines for primary prevention to be developed by the American Heart Association ${ }^{18}$. Evaluation and control of cholesterol levels must be begun at age 20 in both sexes ${ }^{18}$, and after 40 years of age the calculation of absolute risk of cardiovascular events must be done using the Framingham risk tables ${ }^{12}$.

The present campaign did not aim at taking a Brazilian census on cholesterol. In spite of being the largest Brazilian study, the results must be carefully interpreted. Some methodological limitations, such as inclusion of a volunteer population, not being randomized, without economic class or ethnic distinctions, may be a bias of the samples. Furthermore, the proportion of individuals using a lipid-lowering medication was not documented in our sample. The results must be considered as circumstantial and must be considered as a warning to the medical community and to authorities to take adequate preventive measures.

\section{Acknowledgments}

To the doctors for the help given in the campaign Armênio Guimarães(BA), Augusto EliasZ. Bozza(RJ), Benício Sampaio (PI), Carlos A. Machado (SP), Carlos Scherr (RJ), José Portes (SP), José Ernesto dos Santos (SP), Luiz Introcaso (DF), Mariléia Scatezzini (PR), Mario Maranhão (PR), Norma Sabino Pontes (DF), Otávio Rizzi Coelho(SP), Romero Bezerra (DF) and to the financial support received from Laboratório Pfizer do Brasil S.A. 


\section{References}

1. Tunstall-Pedoe H, Kuulasmaa K, Mahonen M, Tolonen H, Ruokokoski E, Amouyel P. Contribution of trends in survival and coronary-event rates to changes in coronary heart disease mortality: 10-year results from 37 WHO MONICA project populations. Monitoring trends and determinants in cardiovascular disease. Lancet 1999; 353: 1547-57.

2. Lolio CA, Lotufo PA, LiraAC. Tendência da mortalidade por doenças isquêmica do coração nas capitais de regiões metropolitanas do Brasil, 1979-1989. Arq Bras Cardiol 1995; 64: 195-99.

3. Scandinavian Simvastatin Survival Study Group: Randomized trial of cholesterol lowering in 4444 patients with coronary heart disease: The Scandinavian Simvastatin Survival Study (4S). Lancet 1994; 344: 1383-9.

4. Shepherd J, Cobbe SM, Ford I, et al for The West of Scotland Coronary Prevention Study Group. Prevention of coronary heart disease with pravastatin in men with hypercholesterolemia. N Eng J Med 1995; 333: 1301-7.

5. Downs JR, Clearfield M, Weiss DO, et al. Primary prevention of acute coronary events with lovastatin in men and women with average cholesterol levels. Results of AFCAPS/TEXCAPS. JAMA 1998; 279: 1615-22

6. LaRosa JC, He J, Vupputuri S. Effect of statins on risk of coronary disease.Ametaanalysis of randomized controlled trials. JAMA 1999; 282: 2340-6.

7. Nicolau JC, Bechara DL, Nascimento SD, Greco OT, Jacob JL, Lorga AM. O perfil do colesterol na cidade de São José do Rio Preto. Arq Bras Cardiol 1992 59: 433-40.

8. Guimaraes AC, Lima M, Mota E, et al. The cholesterol level of a selected Brazilian salaried population: biological and socioeconomic influences. CVD Prevention 1988; 1: 306-17.

9. Acessado na página da internet www.datasus.gov.br
10. Hankey GJ. Role of lipid-modifying therapy in the prevention of initial and recurrent stroke. Curr Opin Lipidol 2002; 13: 645-51.

11. Sirtori CR, Calabresi L, Marchioli R, Rubins HB. Cardiovascular risk changes after lipid lowering medications: are they predictable? Atherosclerosis. 2000; 152: $1-8$.

12. Santos RD, Giannini SD, Fonseca FAH, et al. III Diretrizes Brasileiras de Dislipidemias e Prevenção da Aterosclerose do Departamento de Aterosclerose da Sociedade Brasileira de Cardiologia. Arq Bras Cardiol 2001; 77(Suppl.1): 48.

13. Multiple risk factor intervention trial research group. Multiple risk factor intervention trial. Risk factors changes and mortality reduction. JAMA 1982; 248: 465-1477.

14. Castelli WP. The new pathophysiology of coronary artery disease. Am J Cardiol 1998; 82: 60T-65T.

15. Kannel, WB. The Framingham study: Its 50 years legacy and future promise. J Atheroscler Thromb 2000; 6: 60-6.

16. Hulley S, Grady D, Bush T, et al. Randomized trial of estrogen plus progestin for secondary prevention of coronary heart disease in postmenopausal women. Heart and estrogen/progestin replacement study (HERS) research group. JAMA 1998; 280: 605-13.

17. Writing Group for the Women's Health Initiative Investigators. Risks and Benefits of Estrogen Plus Progestin in Healthy Postmenopausal Women. Principal Results From the Women's Health Initiative Randomized Controlled Trial. JAMA 2002; 288: 321-33.

18. Pearson TA, Blair SN, Daniels SR, et al.AHA Guidelines for Primary Prevention of Cardiovascular Disease and Stroke: 2002 Update Circulation 2002; 106: 388-91. 